\title{
MANAGEMENT INNOVATION - DESIGNING AND TESTING A THEORETICAL MODEL
}

Muamer Bezdrob, Aziz Šunje *

\section{Abstract}

Management innovation - the introduction of management processes, structures and practices that are new to companies, is crucial to business success. Based on the existing literature on management innovation and a rigorous theoretical approach to model design and development, a theoretical model of management innovation that is applicable to immature and underdeveloped markets was designed. Using this model, the study shows that the context in which companies operate, as well as companies' management background (proficiency), are directly and positively related to management innovation. The main implication of the research is that the existing management innovation theory is applicable to market conditions in the Federation of Bosnia and Herzegovina with only slight adaptation. Furthermore, this research provides important insights about the factors that affect the companies' readiness to introduce innovative management structures, processes and practices.

Keywords: Management innovation, Immature markets, Managerial proficiency, Models

JEL classification: M100 - Business Administration: General

\section{INTRODUCTION}

One of the most recent research topics in the field of management and business administration is management innovation - the introduction of management processes, structures and practices that are new to the companies. Even though management innovation is crucial to business success, most organizations focus their innovation efforts on perfecting operational and product innovations. The same odd situation can be found within academia, where scientific and professional works on technological innovation outnumber those on management innovation more than 100-fold (Hamel 2007). Such a situation initiated Hamel, Birkinshaw and Mol to open a new and broad research area (Birkinshaw et al. 2005).

There were some studies on management innovation (Abrahamson 1996; Damanpour 1987, 1991;
Gruber \& Niles 1972, 1974; Kimberly 1981) before Hamel and others initiated their theory, but after these initial studies a number of works on this topic emerged (e.g. Hindle 2008; Birkinshaw \& Mol 2006; Vaccaro et al. $2009,2012)$, among which those that are especially

* Muamer Bezdrob, Ph. D.

Assistant professor

American University in Bosnia and Herzegovina

E-mail: mbezdrob@aubih.edu.ba

Aziz Šunje, Ph. D.

Professor of Management

University of Sarajevo,

School of Economics and Business

E-mail: aziz.sunje@efsa.unsa.ba 
important are works by Fariborz Damanpour (e.g. Damanpour \& Aravind 2012; Damanpour 2014). Most of these previous studies primarily explored the nature and causes of management innovation, as well as who the main actors are in management innovation processes.

Studies that analyze the management innovation process at the organizational level are quite rare and recent (e.g. Mol \& Birkinshaw 2009b; Walker et al. 2011; Černe et al. 2013). Authors of these studies strove to reveal the causes and/or effects of the management innovation process at an organizational level, and they identified a lack of such research work as a major gap in the existing literature

This study built on these previous research and sought to further reduce the identified gap in the literature. We were primarily interested in a general picture of the management innovation phenomenon. More precisely, we were interested in the global situation that influences and encompasses management innovations implementation at the company level. That leads to the first research question of this study:

Q1: What are the main situational factors that determine companies' operational setting, and that have an important and significant influence on management innovation implementation processes?

During our research work on the topic, we realized that all noteworthy management innovations were invented and subsequently described by the professionals, companies and scholars from the most developed countries of modern world. That fact leads to the second research question of this study:

Q2: Is the existing theory and practice of management innovation adaptable and applicable to the conditions of the immature and underdeveloped market of the Federation of Bosnia and Herzegovina?

Furthermore, it was only until recently that one could find literature about management innovation that is related to transitional and developing economies (García-Zamora et al. 2013; Wu et al. 2008), especially studies from the region of South-East Europe, with the exception of a few studies from Slovenia (Černe et al. 2013; Ursič \& Mulej, 2005). Consequently, each study on this topic significantly contributes to the body of literature on management innovation.

In this study we wanted to design an overall theoretical model of management innovation founded on the existing literature. That model had to be simple and empirically verifiable. In addition, we wanted to adapt that model in such way that it could be applied to any market conditions and particularly to those of the Federation of Bosnia and Herzegovina (F B\&H). Finally, we wanted to have a model that is fully open for modifications and applicable for future research.

\section{LITERATURE REVIEW}

Early works related to management innovation could be found in the 1970s and later on (e.g. Abrahamson 1991, 1996; Gruber \& Niles 1972, 1974; Teece 1980) but it was not until very recently that one could find more works on that topic (e.g. Hervás-Oliver \& Peris-Ortiz 2014; Hindle 2008; Walker et al. 2011; Hollen et al. 2013). Furthermore, all of these research activities provide few insights about how to improve management innovation capacity or about the true origins of management innovation (Birkinshaw et al. 2005, 2008).

In addition, the most important management innovations came from truly innovative business organizations (Hamel 2006) but the same absence of interest in the process of management innovation could be found among the practitioners of management. Even though some authors argued that a lack of management innovation is the most serious problem for competitiveness (Stata 1989, 2002) a systematic approach to the process of management innovation could not be noted within companies in general (Birkinshaw et al. 2005).

\subsection{Management Innovation - The Theory Foundation}

Based on Abrahamson's "Management fashion" theory (Abrahamson 1991, 1996; Abrahamson \& Fairchild 1999) Birkinshaw, Hamel and Mol have developed their management innovation theory. Pursuant to the title of Hamel's HBR article (Hamel 2006) they focused their interest on three questions - the "why", "what" and "how" of management innovation.

In his book, The Future of Management (2007), Hamel challenges the mere concept of today's management and explains the reasons why management should be reinvented. First, modern management resides on premises that were laid down at the beginning of the $20^{\text {th }}$ century and are based on centralized control and high efficiency. Hamel argues that such management practices are not adequate for $21^{\text {st }}$ century companies and, consequently, a completely new management paradigm should be invented (Hamel $2007,2009)$. Another argument that he poses is that management innovations can create a powerful and long-standing competitive advantage that cannot be surpassed by any other kind of innovation (Hamel 
2006). Similarly, Birkinshaw argues that the basic purpose of management has been corrupted over the years. He suggests that managers should seek smarter choices about how the work gets done in order to improve management in the future (Birkinshaw 2010).

Regarding the "what" question, above all a comprehensive and clear definition of the term "management innovation" should be established. This research treats management innovation as: "the implementation of management practices that are new to the firm and intended to enhance firm performance (2009b: 1269)" (Mol \& Birkinshaw 2009b).

There are four critical elements in this definition that profoundly explain the concept of management innovation and that should be emphasized. First, the term "management practices" implies all possible managerial activities that managers undertake in their work (Hamel 2006). Second, it clearly states the level of novelty of those activities - they do not have to be new to the world but only to the adopting organization (e.g. McCabe 2002; Yang et al. 2007). Third, management innovation assumes the implementation of those activities inside the real world organization and not the development of a scientific idea (Birkinshaw et al. 2008). Finally, the fourth element, the intention to further the organization's goals, expresses the primary reason why organizations undertake management innovation at all and accept all the risk that such a process brings about (Birkinshaw et al. 2005).

The processes of management innovation or how management innovations occur on the operational level represent the third pillar of management innovation theory. Earlier literature on management innovation explains the reasons why and how some management innovations are accepted and diffused (Abrahamson 1991, 1996). On the other hand, it does not provide any details on how those innovations happen on the operational level. For that purpose, Birkinshaw, Hamel and Mol (2008) have developed a framework that describes the management innovation process. According to this framework, there are four interlinked phases of the process (motivation, invention, implementation and theorization and labeling) and two key players (internal change agents and external change agents). The authors of this framework further explain that innovation emerges through a complex sequence of identified phases in which two groups of agents mutually interact through ten core innovation activities.

\subsection{Management Innovation - The Model}

Most of the management innovation literature is focused on high level understanding of the management innovation phenomenon (Kimberly 1981; Abrahamson 1996; Birkinshaw et al. 2005, 2008; Hamel 2006, 2012). There is also plenty of research work on specific aspects of management innovation implementation (Kossek 1987; Nickell et al. 2001; McCabe 2002; Hargrave \& Van de Ven 2006) and some research work about the effects of management innovations on the adopting organizations (Biagi et al. 2008; Bryson et al. 2009). At the same time, management innovation research work on the company level is quite rare. Because of that fact, we have focused our research effort on building a theoretical model of management innovation, which links management innovation and the situational factors of the organization.

Similar reasons have led Mol and Birkinshaw to conduct research on the relationship between the context in which organizations operate and the organizations' search for knowledge sources and management innovation (Mol \& Birkinshaw 2009b). They have conducted empirical research based on the UK Community Innovation Survey (CIS3 and CIS4) in order to find out what explains management innovation best (Mol \& Birkinshaw 2009a). Likewise, Hecker and Ganter (2013) have used the German Community Innovation Survey (CIS IV) to empirically validate the relationship between competition, as an indicator of industry dynamics, and a company's inclination to innovate.

According to these research activities, the context, defined as a set of organizational attributes (Mol \& Birkinshaw 2009b), represents an important determinant of management innovation. Thus we propose our first hypothesis as:

\section{H1: Organizational context has a direct and positive impact on management innovation.}

Some studies have discussed the interaction between management innovation and the different constituents of an organization (Nguyen \& Mothe 2008; Vaccaro et al. 2009; Kunz \& Linder 2011). Nguyen and Mothe (2008) looked into the impact of organizational innovation (defined as the changes in management practices, production approaches and external relations) on a company's aptitude to innovate, and found a direct and positive relationship between the two. Here, innovation is considered in accordance with Damanpour's (1992) definition of innovation. On the other hand, Kimberly and Evanisco (1981), who later in his works confirms Damanpour $(1987,1991)$, have found that functional differentiation is positively associated with the acceptance of administrative innovations.

Assuming that a positive relation between the two types of innovation works two-ways, and as structural 
changes usually accompany technical (and technological) innovations, we submit the second hypothesis as:

H2: Production and structural innovation has a direct and positive impact on management innovation.

Here the term "production innovation" relates to the product (service) innovation as well as the production (service) process innovation.

The authors of the previously mentioned studies on management innovation have found a positive link between management innovations and characteristics of the top management team (Vaccaro et al. 2009, 2012) as well as the personal traits of employees (Kunz \& Linder 2011). Similarly, some studies have found that employee education level is positively related to management innovation (Mol and Birkinshaw 2009b), as well as the ability of the employees to exchange existing knowledge (Černe et al. 2013). Furthermore, management innovation theory points to internal change agents (Birkinshaw et al. 2008; Mol and Birkinshaw 2014) as a group of key players who carry out the management innovation process. Thus, in accordance with all of these findings we propose the following hypothesis:

H3: The organization's management proficiency has a direct and positive impact on management innovation.

Under the term "management proficiency" we imply management team diversity (Vaccaro et al. 2009), the management (organizational) learning system (formal and experience-based learning system) as well as management expert foundation. It relates to overall management expertise, existing and potential, that the company possesses. Bearing in mind this elaboration, the following hypothesis is offered:
H4: The organization's management proficiency has a direct and positive impact on production and structural innovation.

These four hypotheses determine our management innovation theoretical (conceptual) model, which is graphically presented in Figure 1.

\subsection{Management Innovation - Market Status in Bosnia and Herzegovina}

Bosnia and Herzegovina, a country located in Southeastern Europe (SEE), is a small open economy whose GDP represents $0.035 \%$ of world GDP and whose population represents $0.048 \%$ of the world's population (Čaušević 2012). During the devastating war from 1992 to 1995, industrial production and GDP plummeted by almost 80\%, but from 1996 to 2007 Bosnia and Herzegovina recorded substantial economic growth (average GDP growth rate was 11,2\%), which at the time represented the $17^{\text {th }}$ fastest growing economy in the world. During the global economic crisis this growth was significantly slowed down to around 1\% (Čaušević 2012).

With its GDP per capita of 4,675 US\$ (the Central Bank of Bosnia and Herzegovina 2014), Bosnia and Herzegovina belongs to the group of developing countries. According to the Doing Business 2015 report, Bosnia and Herzegovina is ranked $107^{\text {th }}$, which is the lowest rank in the SEE region and far below the regional average (World Bank 2014). Considering its main economic indicators as well as the general business climate, Bosnia and Herzegovina lags far behind most developed countries.

Last but not least, inefficient administration, government instability and the tax burden are probably the biggest obstacles to faster economic development and a better business climate. Taken all together,

Figure 1. Conceptual model of management innovation

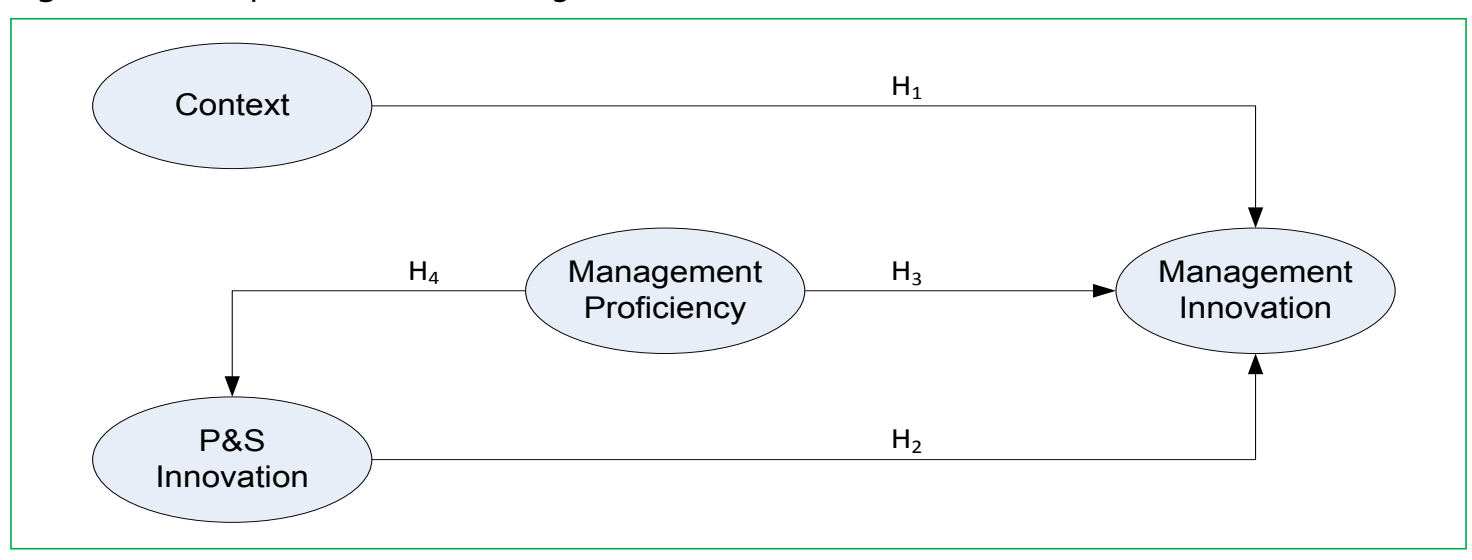


these facts yield market conditions in (Federation) Bosnia and Herzegovina that are significantly different from those of the most developed countries.

All the foregoing references to the theoretical foundations of management innovation originate from the most developed countries of the world. However, the applicability of these theoretical and practical propositions to the countries of the developing world is of great importance. It is often assumed that something accepted in the most developed countries is globally applicable as a "best practice" irrespective of local circumstances (Blunt 2002). However, recent studies show that the best management practices do not necessarily work under different conditions (Khanna 2014). Furthermore, there is a tendency to object when theory and practice differ, and, consequently, there are few research works on the subject of the modification of management innovation (Mamman 2009).

For all of these reasons, one of the most important goals of this research is to adapt the existing knowledge base in order to design and test a theoretical model of management innovation that is applicable to immature and underdeveloped markets, such as the market of the $F B \& H$.

\section{DATA AND METHODOLOGY}

In the spirit of good research (McGrath 1981) we used a sequential mixed-method research in order to obtain a high level of results credibility. The first part of the research makes up an exploratory qualitative study aimed at providing a deeper understanding of management innovation processes in the circumstances of the immature and underdeveloped market of the F B\&H. The second part of the research makes up a quantitative study aiming to confirm the findings and test the proposed hypotheses.

\subsection{The Qualitative Study}

The qualitative part of our research consists of 14 semi-structured interviews that were conducted with 14 participants selected from within three broad groups: academia, top-management and the business consultant community. We used the maximumvariation sampling scheme in order to obtain multiple perspectives from the participants (Onwuegbuzie \& Leech 2007), where professional background was the main participant selection determinant.

Regarding the sample size, we followed a general rule stating that the sample should be big enough to enable data saturation but not too big to prevent a deep analysis of the collected data. There are many practical recommendations regarding the sample size (Onwuegbuzie \& Leech 2007; Guest et al. 2006) but the most usual recommendation is $12-20$ interviews. We found that the data saturation occurs after $10^{\text {th }}$ interviewee, but to be on the safe side we have decided to have at least four participants per group. Thus, we conducted 14 interviews.

The interviews consisted of 14 to 16 questions, with each question introducing a particular topic that the interviewees were asked to comment on. In order to reduce any bias in answers or a propensity to answer in favor of the research subject less than half of the interview questions/topics were directly related to management innovations.

The procedure we used to analyze the collected data is known as subsequent content analysis (Srnka \& Koeszegi 2007), which represents an integrated qualitative-quantitative research method. We used integral thoughts as data units that are numerically coded in accordance with the category scheme, which consists of 12 main categories, with up to two subcategories, resulting in a total of 16 categories. These 12 main categories are compacted into four super-categories.

Due to the abundance of the collected data, the unitization was done jointly by two of us, so we finally obtain 969 thought units. The coding of the obtained thought units was done independently by two coders. For each interview question/topic (" $Q$ ") one to three generic answers ("GA") were offered. Thereafter, coders had to assign a category and, if applicable, a corresponding subcategory to each thought unit. This category assignment was based on the coder's conception of the relation between the generic answers and thought units.

Using the Cohen's kappa for checking the coding consistency between the two coders (Wood 2007) we have yielded an inter-rater reliability coefficient over the super-category "Attitude" of $\mathrm{K}=0.88$. It is generally considered that kappa values over 0.8 are a very good result (Srnka \& Koeszegi 2007). Thus, we have concluded that we have an almost $100 \%$ agreement between the coders and that we could use any coding (from any of the two coders).

The results of the data analysis are shown in Table 1. Since the chosen procedure provides a quantification of qualitative data, it was easy to conduct a frequency analysis of the derived quantitative data. Thus, we agreed that if more than two thirds of the respondents had the same opinion about a particular topic then we could consider that opinion a general stand toward the generic answer. Accordingly, we set the separation threshold at $70 \%$. 
Table 1. Topics Directly Related to Management Innovation

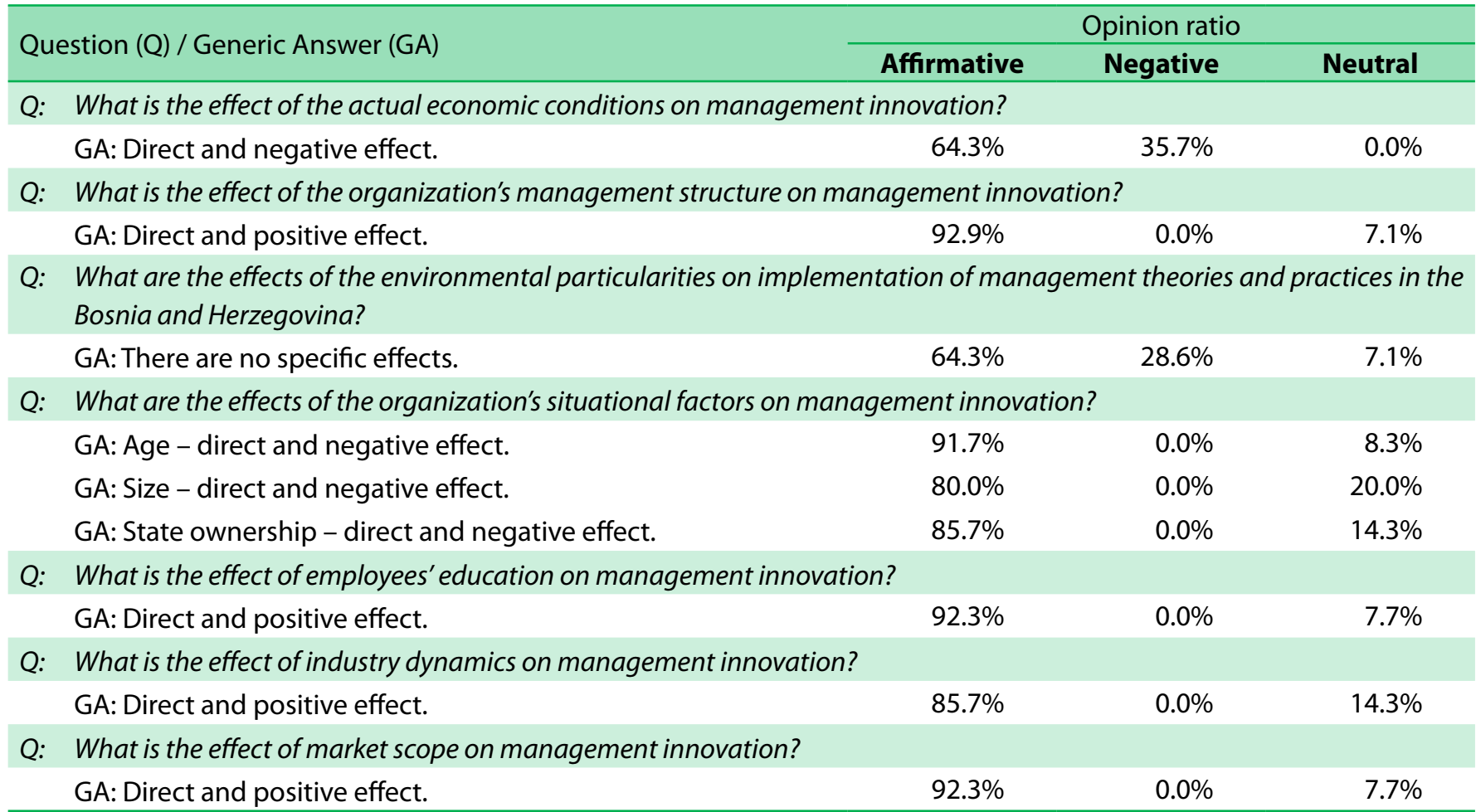

It can be seen in Table 1 that all generic answers are confirmed except for two topics. Particularly interesting is the third listed topic in Table 1. It shows that there is a notable divergence in opinions related to the applicability of management theories and practices within the emerging market of Bosnia and Herzegovina, which is a very important issue for this research.

Combining the theoretical background represented through the proposed hypotheses with the results of this qualitative research we have designed a theoretical (empirical) model of management innovation that is adapted to comply with the immature and underdeveloped market conditions of F B\&H. The model is shown in Figure 2.

\subsection{The Quantitative Study}

To test the hypothesized model we conducted a survey among the companies that are registered in the

Figure 2. Empirical model of management innovation

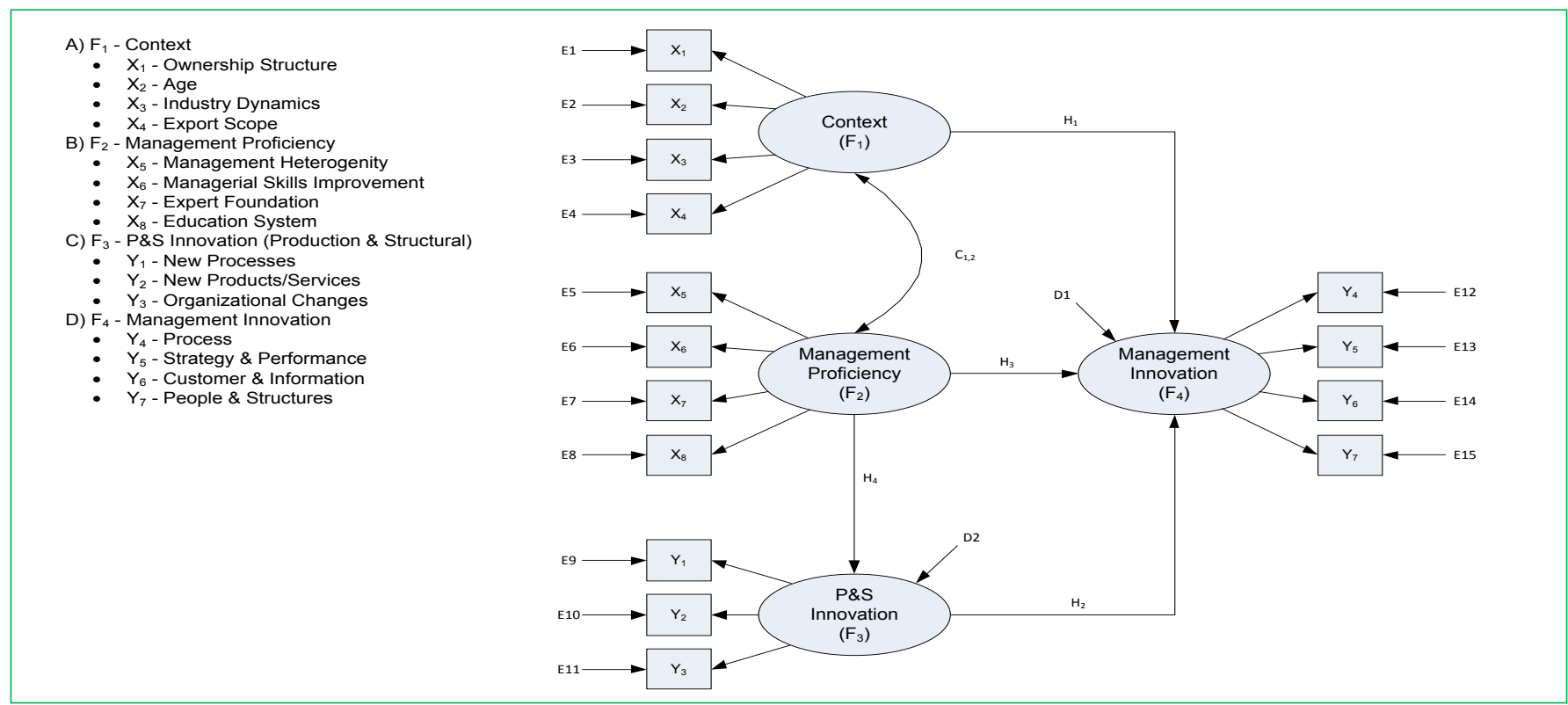


$\mathrm{F} \mathrm{B \& H}$. The questionnaire was sent to 310 companies that were randomly chosen from the whole population of the companies that comply with the following profile:

- employing at least 20 people

- established in 2001 or earlier

- not belonging to the financial, health care, social welfare, educational or public sectors.

We received 186 responses (60\%), out of which 160 were valid $(51.61 \%)$. The responding companies had an average size of 180.2 (S.D. 358) employees and an average age of 16.5 (S.D. 4) years. The estimated population of the companies that comply with the described profile is 1400 , so the expected statistical error is around $7 \%$ with a confidence level of $95 \%$.

\subsubsection{Measures}

All variables in the model were measured using data from the conducted survey and from the official balance reports of the corresponding companies. The measurement spans the five-year period from 2006 to 2010.

\subsubsection{Context $\left(F_{1}\right)$}

This construct is related to the context in which the companies operate. We used a four-indicator measure for this construct:

- "Ownership Structure" $\left(X_{1}\right)$ - ranks (state ownership - rank 1; 100\% foreign capital - rank 8) companies based on the ownership type and foreign capital share.

- "Age" $\left(X_{2}\right)$ - ranks (youngest - rank 1; oldest - rank 8) companies based on their life span from the year of incorporation to the year 2011.

- "Industry Dynamics" $\left(X_{3}\right)$ - ranks (least dynamic rank 1; most dynamic - rank 4) companies based on the dynamics of the industry sector to which they belong.

- "Export Scope" $\left(X_{4}\right)$ - ranks companies based on a ratio of exporting revenue to total revenue $(<5 \%-$ rank $1 ; 5-30 \%$ - rank $2 ;>30 \%$ - rank 3 ).

\subsubsection{Management Proficiency $\left(F_{2}\right)$}

This construct is related to the managerial potential that the company has both within its management team and non-managerial staff. We used a fourindicator measure for this construct:

- "Management Heterogeneity" $\left(X_{5}\right)$ - ranks (1-6) companies based on the number of top-managers and their experience in different functional areas, controlling for the size of the company (determined by the number of employees). The lowest ranked companies (rank 1) are those with the smallest number of top-managers with the same profession, and companies with an optimal number of top-managers with different professions have the highest rank (6).

- "Managerial Skills Improvement" $\left(X_{6}\right)$ - ranks companies based on whether they employed external management consultants (rank 3), organized specialist training for their managers (rank 2) or both (rank 4).

- "Expert Foundation" $\left(X_{7}\right)$ - ranks (1-7) companies based on the ratio of employees with a graduate level degree to the total number of employees.

- "Education System" $\left(X_{8}\right)$ - ranks (1-9) companies based on their training plans and educational budget. The lowest ranked companies (rank 1) are those with the smallest budget for education and with sporadic trainings for small groups of employees, and companies with the biggest educational budget and with regular trainings for all employees have the highest rank (9).

\subsubsection{Production \& Structural Innovation $\left(F_{3}\right)$}

To measure this construct we used a very simple three-indicator measure which refers to the level of innovative activities within the companies' production systems and structures. Those three indicators are:

- "New Processes" $\left(Y_{1}\right)$ - ranks companies based on whether they introduced new production processes (rank 3), modified old production processes (rank 2) or both (rank 4).

- "New Products/Services" $\left(Y_{2}\right)$ - ranks companies based on whether they introduced new products (rank 3), modified old products (rank 2) or both (rank 4).

- "Organizational Changes" $\left(Y_{3}\right)$ - ranks companies based on whether they introduced a new managerial structure (rank 3), made changes to the existing managerial structure (rank 2) or both (rank 4).

\subsubsection{Management Innovation $\left(F_{4}\right)$}

In accordance with the list of the most relevant and noteworthy innovations in all areas of management (Mol \& Birkinshaw 2007), we produced a set of indicators that measure this construct. Those indicators are as follows:

- "Process" $\left(Y_{4}\right)$ - ranks (1-5) companies based on the implementation of the following management practices and structures: Quality Management System, TQM, $6 \sigma$, Supply Chain Management and Lean Manufacturing.

- "Strategy\& Performance" $\left(Y_{5}\right)$ - ranks (1-3) companies 
based on the implementation of the following management practices and structures: BSC, EVA, Strategy Planning and Benchmarking.

- "Customer \& Information" $\left(Y_{6}\right)$ - ranks (1-3) companies based on the implementation of the following management practices and structures: Brand Management, CRM, Operations Research and ERP.

- "People \& Structures" $\left(Y_{7}\right)$ - ranks (1-3) companies based on the implementation of the following management practices and structures: HRM, 360-degree Feedback, PMO and Matrix Organization.

The generated four-indicator measure provides a measurement scale that shows an aggregate level of innovative activities from the management domain.

\subsubsection{Results}

All variables from the model are measured on an ordinal scale. Table 2 contains the means and standard deviations of and covariance between all model variables, where alternative parameterization is used for the underlying variables of the model's ordinal variables (Jöreskog 2004).

To test the hypothesized model we employed structural equation modeling (SEM) because it enables a concurrent testing of several dependence relationships within a single theoretical model (Hair et al. 2009). Following the two-step approach (Anderson \& Gerbing 1988) we used LISREL 8.80 for both measurement and structural model testing.

\subsubsection{Assumptions}

The assumptions were evaluated through SPSS and LISREL. The dataset contains responses from $160 \mathrm{com}$ panies. There were no missing data and no univariate outliers. Considering that the hypothesized model has only four constructs, each with at least three indicators, this sample size is just adequate for the model estimation (Hair et al. 2009).

Since we dealt with ordinal data both univariate and multivariate normality were violated. All variables showed a moderate non-normality (skew $<2$, kurtosis $<7$ ) except variable $Y_{4}$ (skew $>2$ ). Thus, in accordance with the recommendation for dealing with non-normal and ordinal data (Finney \& DiStefano 2006), the Satorra-Bentler scaling method for $\chi^{2}$ and standard errors is used for model estimation.

Table 2. Means, Standard Deviations and Covariance between Model Variables

\begin{tabular}{|c|c|c|c|c|c|c|c|c|c|c|}
\hline & Variable & Mean & S.D. & 1 & 2 & 3 & 4 & 5 & 6 & 7 \\
\hline 1 & Ownership Structure & 2.19 & 0.88 & 0.77 & & & & & & \\
\hline 2 & Age & 1.13 & 1.07 & -0.44 & 1.14 & & & & & \\
\hline 3 & Industry Dynamics & 1.17 & 0.56 & 0.13 & -0.10 & 0.32 & & & & \\
\hline 4 & Export Scope & 0.12 & 1.13 & -0.18 & 0.20 & -0.27 & 1.27 & & & \\
\hline 5 & Mgmt. Heterogeneity & 2.74 & 1.96 & -0.18 & 0.10 & 0.04 & -0.17 & 3.85 & & \\
\hline 6 & Managerial Skills Impr. & 0.63 & 1.29 & 0.08 & 0.03 & -0.02 & 0.05 & 0.44 & 1.67 & \\
\hline 7 & Expert Foundation & 1.76 & 2.27 & 0.09 & -0.04 & 0.15 & 0.02 & 0.38 & 0.80 & 5.14 \\
\hline 8 & Education System & 2.21 & 2.77 & -0.06 & -0.45 & -0.09 & -0.04 & 0.94 & 1.73 & 1.77 \\
\hline 9 & New Processes & 1.59 & 1.34 & 0.06 & -0.20 & -0.04 & -0.13 & 0.10 & 0.49 & 0.33 \\
\hline 10 & New Products/Services & 1.92 & 1.54 & 0.00 & -0.06 & 0.00 & -0.01 & 0.43 & 0.49 & 0.52 \\
\hline 11 & Organizational Changes & 1.23 & 1.82 & 0.13 & -0.22 & -0.09 & -0.11 & 0.49 & 0.83 & 0.69 \\
\hline 12 & Process & -3.19 & 3.00 & 1.02 & 0.01 & -0.22 & 0.13 & -0.23 & 0.62 & 0.53 \\
\hline 13 & Strategy \& Performance & -0.90 & 1.07 & 0.41 & -0.28 & 0.08 & -0.12 & 0.20 & 0.47 & 0.30 \\
\hline 14 & Customer \& Information & -1.08 & 1.22 & 0.29 & -0.33 & 0.14 & 0.05 & 0.14 & 0.39 & 0.77 \\
\hline 15 & People \& Structures & -0.87 & 1.00 & 0.25 & -0.30 & 0.04 & -0.01 & -0.02 & 0.44 & 0.67 \\
\hline
\end{tabular}

Table 2. Means, Standard Deviations and Covariance between Model Variables (Cont'd)

\begin{tabular}{|c|c|c|c|c|c|c|c|c|c|}
\hline & Variable & 8 & 9 & 10 & 11 & 12 & 13 & 14 & 15 \\
\hline 8 & Education System & 7.66 & & & & & & & \\
\hline 9 & New Processes & 1.26 & 1.80 & & & & & & \\
\hline 10 & New Products/Services & 0.85 & 1.49 & 2.37 & & & & & \\
\hline 11 & Organizational Changes & 1.50 & 1.32 & 1.05 & 3.32 & & & & \\
\hline 12 & Process & 1.71 & 0.39 & 0.16 & 1.47 & 9.01 & & & \\
\hline 13 & Strategy \& Performance & 0.82 & 0.40 & 0.52 & 0.59 & 1.70 & 1.14 & & \\
\hline 14 & Customer \& Information & 1.29 & 0.62 & 0.64 & 0.46 & 1.56 & 0.78 & 1.48 & \\
\hline 15 & People \& Structures & 0.88 & 0.48 & 0.35 & 0.55 & 1.64 & 0.78 & 0.80 & 1.00 \\
\hline
\end{tabular}




\subsubsection{Measurement Model}

Measurement model fitting is examined through several absolute, incremental and parsimony goodness-of-fit indices (Table 3). All these fit indices suggest an acceptable fit for the measurement model.

Construct validity is assessed through convergent validity, discriminant validity and nomological validity. All factor loading estimates are in the expected direction and all are statistically significant as required for convergent validity.

Table 3 displays the standardized factor loadings for the measurement model. It could be seen from Table 3 that factors $F_{1}$ and $F_{2}$ have loadings that fall well below the cutoff value -0.5 and preferably 0.7
(Hair et al. 2009), what makes them candidates for removal from the model. Consequently, the estimates of the average variance extracted (AVE) for above listed factors are below the preferable value of 0.5 , but above the cutoff value of 0.25 . In addition, the construct reliability (CR) estimates are all almost 0.6 (cutoff value) or higher (Hair et al. 2009). Combining these results with the fact that the overall model fits well we proceed with our modeling being aware of this limitation but giving more weight to the theoretical arguments over statistical tests.

All AVE estimates for the model's constructs are greater than the squared inter-construct correlations (Table 4), which indicates that there are no problems with discriminant validity. Moreover, there are no

Table 3. Standardized Factor Loadings, Average Variance Extracted, Reliability Estimates

\begin{tabular}{|c|c|c|c|c|}
\hline & $\mathrm{F}_{1}$ & $\mathrm{~F}_{2}$ & $\mathrm{~F}_{3}$ & $\mathrm{~F}_{4}$ \\
\hline ("Ownership Structure") - X & $0.85^{* * *}$ & & & \\
\hline$\left(\right.$ ("Age") $-\mathrm{X}_{2}$ & $-0.55^{* * *}$ & & & \\
\hline ("Industry Dynamics") $-\mathrm{X}_{3}$ & $0.34^{*}$ & & & \\
\hline$\left(\right.$ ("Export Scope") $-\mathrm{X}_{4}$ & $-0.25^{*}$ & & & \\
\hline ("Management Heterogeneity") - $\mathrm{X}_{5}$ & & $0.22^{*}$ & & \\
\hline ("Managerial Skills Improvement") - $\mathrm{X}_{6}$ & & $0.68^{* * *}$ & & \\
\hline ("Expert Foundation") $-\mathrm{X}_{7}$ & & $0.40^{* * *}$ & & \\
\hline ("Education System") - $\mathrm{X}_{8}$ & & $0.72^{* * *}$ & & \\
\hline ("New Processes") $-Y_{1}$ & & & $0.95^{* * *}$ & \\
\hline ("New Products/Services") $-Y_{2}$ & & & $0.75^{* * *}$ & \\
\hline ("Organizational Changes") $-\mathrm{Y}_{3}$ & & & $0.57^{* * *}$ & \\
\hline$\left(\right.$ ("Process") $-\mathrm{Y}_{4}$ & & & & $0.61^{* * *}$ \\
\hline ("Strategy \& Performance") $-Y_{5}$ & & & & $0.84^{* * *}$ \\
\hline (“Customer \& Information") $-\mathrm{Y}_{6}$ & & & & $0.74^{* * *}$ \\
\hline ("People \& Structures") $-Y_{7}^{0}$ & & & & $0.87^{* * *}$ \\
\hline Average Variance Extracted (AVE) & $30.1 \%$ & $29.7 \%$ & $59.7 \%$ & $59.6 \%$ \\
\hline Construct Reliability (CR) & 0.58 & 0.59 & 0.81 & 0.79 \\
\hline Goodness-of-Fit Indices (GoF) & \multicolumn{4}{|c|}{$\begin{array}{l}\chi^{2}=78.739(\mathrm{df}=84, \mathrm{p}=0.642) \\
\mathrm{RMSEA}=0.0 ; 90 \% \mathrm{Cl} \text { of } \mathrm{RMSEA}=0.0-0.0378 \\
\mathrm{SRMR}=0.0746 ; \mathrm{CFI}=1 ; \mathrm{PNFI}=0.746\end{array}$} \\
\hline
\end{tabular}

${ }^{* * *}$ - significant at $0.001 ;{ }^{*}$ - significant at 0.05

Table 4. Average Variance Extracted (AVE) and Squared Inter-construct Correlations ( $\left.\boldsymbol{C}_{\boldsymbol{i}, \boldsymbol{j}}^{\mathbf{2}}\right)$

\begin{tabular}{|c|c|c|c|c|c|}
\hline & Construct & $\mathrm{F}_{1}$ & $\mathrm{~F}_{2}$ & $\mathrm{~F}_{3}$ & $\mathrm{~F}_{4}$ \\
\hline$F_{1}$ & $\begin{array}{c}C_{1, j}^{2} \\
\min \left\{\operatorname{AVE}\left(F_{1}\right), \operatorname{AVE}\left(F_{j}\right)\right\}\end{array}$ & $\begin{array}{r}1.000 \\
\%\end{array}$ & & & \\
\hline $\mathrm{F}_{2}$ & $\begin{array}{c}C_{2, j}^{2} \\
\min \left\{\operatorname{AVE}\left(F_{2}\right), \operatorname{AVE}\left(F_{j}\right)\right\}\end{array}$ & $\begin{array}{l}0.002 \\
0.297\end{array}$ & $\begin{array}{r}1.000 \\
\%\end{array}$ & & \\
\hline $\mathrm{F}_{3}$ & $\begin{array}{c}C_{3, j}^{2} \\
\min \left\{\operatorname{AVE}\left(F_{3}\right), \operatorname{AVE}\left(F_{j}\right)\right\}\end{array}$ & $\begin{array}{l}0.007 \\
0.301\end{array}$ & $\begin{array}{l}0.214 \\
0.297\end{array}$ & $\begin{array}{r}1.000 \\
\%\end{array}$ & \\
\hline $\mathrm{F}_{4}$ & $\begin{array}{c}C_{4, j}^{2} \\
\min \left\{\operatorname{AVE}\left(F_{4}\right), \operatorname{AVE}\left(F_{j}\right)\right\}\end{array}$ & $\begin{array}{l}0.241 \\
0.301\end{array}$ & $\begin{array}{l}0.292 \\
0.297\end{array}$ & $\begin{array}{l}0.170 \\
0.596\end{array}$ & $\begin{array}{r}1.000 \\
\%\end{array}$ \\
\hline
\end{tabular}


cross-loadings among either indicators or error terms, so these results tell us that discriminant validity is provided as well. Nomological validity is supported by the fact that all of the correlations between the constructs are positive just as was predicted, and all but two inter-construct correlations are statistically significant.

\subsubsection{Structural Model}

The second stage in this two-step approach is structural model testing, which consists of structural model specification and assessment of structural model validity. Model specification, which implies proposing hypotheses and establishing structural relationships, was described above. It is visually presented by the structural diagram in Figure 2. Structural model validity assumes an assessment of the overall model fit and the examination of model diagnostics (Hair et al. 2009).

Structural model fitting is examined through the same goodness-of-fit indices as for the measurement model (Table 5). All these fit indices suggest that the structural model provides a very good overall fit as well.

The final step in structural model validation is the examination of structural path estimates (Table 5). It could be seen that all but one of the structural path estimates are statistically significant and in the predicted direction. The path between factors $\mathrm{F}_{3}$ and $\mathrm{F}_{4}$ is in the expected direction, but its $t$-value is below the critical level for a Type I error of 0.05 , hence it is not supported. On the other hand, given that three of four estimates are in compliance with the proposed hypotheses, these results provide strong support for our theoretical model.

The chi-square difference between the structural and the measurement model is $\Delta \chi^{2}=0.56$ with one degree of freedom $(p>0.05)$. The insignificant chi-square difference indicates that the model fit could not be improved by estimating another structural path.

For both the measurement and structural model there was only one standardized residual greater than |4.0| and modification indices point only to the addition of covariance between the error terms of indicators. Thus, we have concluded that there is no need for further model modification.

\section{DISCUSSION}

This study provides a deeper understanding of management innovation processes under the conditions of the market environment in the Federation of Bosnia and Herzegovina.

During the model design phase we found out that virtually all theoretical propositions apply to the economic and market circumstances of the $\mathrm{F} \mathrm{B \& H}$. However, our research also showed a notable divergence in opinions related to the applicability of management theories and practices to the same market. Such a somewhat contradictory stand is typical for the turbulent environment of the F B\&H. We strongly believe that this case clearly illustrates the reality of life in the $\mathrm{F} B \& H$, which only contributes to model validity. Strong support for most of the proposed hypotheses goes in favor of that assertion.

The results obtained by testing the measurement model, as well as the structural model (Figure 2), indicate an excellent fit between the theoretical model and the real world represented by the data sample. All observed goodness-of-fit indices (Table 3 ) confirm that the model imposed covariance matrix $(\Sigma)$ is similar to the data sample covariance matrix $(S)$. Such results from SEM analysis point to overall empirical model validity (the measurement validity of all

Table 5. Structural Path Estimates

\begin{tabular}{|c|c|c|c|c|}
\hline $\begin{array}{c}\text { Structural } \\
\text { Relationship }\end{array}$ & $\begin{array}{l}\text { Unstandardized } \\
\text { Parameter } \\
\text { Estimate }\end{array}$ & $\begin{array}{l}\text { Standard } \\
\text { Error }\end{array}$ & t-value & $\begin{array}{l}\text { Standardized } \\
\text { Parameter } \\
\text { Estimate }\end{array}$ \\
\hline H1: F1àF4 & 0.54 & 0.21 & 2.65 & $0.45^{* *}$ \\
\hline H2: F3àF4 & 0.13 & 0.09 & 1.48 & 0.18 \\
\hline H3: F2àF4 & 0.45 & 0.14 & 3.26 & $0.44^{* *}$ \\
\hline H4: F2àF3 & 0.68 & 0.17 & 3.98 & $0.46^{* * *}$ \\
\hline $\operatorname{Cov}(\mathrm{F} 1, \mathrm{~F} 2)$ & 0.04 & 0.09 & 0.40 & $\%$ \\
\hline \multicolumn{2}{|c|}{ Goodness-of-Fit Indices (GoF) } & \multicolumn{3}{|c|}{$\begin{array}{l}X^{2}=79.295(d f=85, p=0.654) \\
R M S E A=0.0 ; 90 \% C I \text { of RMSEA }=0.0-0.0371 \\
S R M R=0.0754 ; C F I=1 ; P N F I=0.755\end{array}$} \\
\hline
\end{tabular}

${ }^{* * *}$ - significant at $0.001 ;{ }^{* *}-$ significant at 0.01 
proposed constructs).

The most important part of SEM analysis, the model's structural path analysis (Table 5), has revealed that three out of the four proposed hypotheses are confirmed (paths estimates are statistically significant at least with $p<0.01$ ), which results from an inter-constructs direct effects analysis. Consequently, the following can be asserted:

1. The context in which companies operate has a direct and positive effect on management innovation, which supports our first hypothesis. This finding is in accordance with previous studies (Mol \& Birkinshaw 2009a, 2009b). Furthermore, we enriched the model with a few other contextual attributes - ownership, age and industry dynamics.

2. The overall management proficiency, and not only top-management team traits (Camelo-Ordaz et al. 2006), as well as high levels of knowledge and knowledge gathering, not only about management but in general, are conducive to management innovation. This finding is in line with previous research (Kunz \& Linder 2011; Vaccaro et al. 2009) and it supports our third hypothesis.

3. The level of structural and production innovation is predicted with the overall management proficiency, which supports the last hypothesis of this study.

4. Even though we found that a positive relation exists between management innovation and production and structural innovation, that relation was statistically insignificant. Thus, our analysis did not support the second research hypothesis.

The coefficient of determination $\left(R^{2}\right)$ for the Management Innovation factor has a value of 0.53 , meaning that the model explains $53 \%$ of the variance of this factor. Such a fairly large effect points to significant model explanatory value.

The strong support for the proposed hypotheses suggests that the context in which the company operates and especially the company's managerial proficiency determine its aptitude for management innovation. At the same time, we found that there is no significant relation between management innovation and the technological innovativeness of companies, which is a rather interesting and unexpected finding.

Even though the main intent of this study is only to propose and test the theoretical model of innovation management, which would then be used as a basis for future research on the management innovation phenomenon, some further suggestions could be drawn based on the results of the study.

Building on the argumentation that management innovation is crucial to business success, the proposed management innovation model could help both academics and practitioners of management to comprehend some very important aspects of the management innovation implementation process, in order to increase the odds of long-term business thrive.

More specifically, a successful validation of the proposed theoretical model provides important insights about how and which factors affect the companies' readiness to introduce innovative management structures, processes and practices. Investing time, effort and money in managerial capacity building on every management level within the organization, and fostering professional diversity among managers will significantly increase not only management innovation capability but the overall organizations' innovation potential.

Naturally, given the fact that management innovation is the most neglected type of innovation, the necessary condition for such an outcome is a radical behavioral change, meaning that academics, as well as top managers, should embrace management innovation as one of the most potent sources of long-lasting organizational competitive advantage.

\section{FUTURE RESEARCH}

In addition to the findings and insights resulting from model testing, we have also initiated research activities about management innovation within immature and underdeveloped markets. We designed a theoretical model of management innovation that can be applied in any economic context. What is more important, our model can be used as a basis for further development and improvement of the understanding of the management innovation concept. While most of studies about management innovation focus on why and how management innovations happen (Birkinshaw et al. 2005; Hamel 2006), we have focused our efforts on describing just what constitutes the management innovation phenomenon within the world of business.

In addition, this research and its results contribute to the body of knowledge related to management innovation by designing an applicable model with corresponding constructs and individual indicator items, i.e. by designing measurement scales and types that could be used for future research.

However, there are a few different limitations that apply to this research. First, we focused only on management innovations that are new to the company, so the study focuses on only one aspect of management innovation. Second, in order to keep the model simple we have used only a limited set of observed variables and, as a consequence, a smaller portion of the 
constructs' variance was explained. Future research could seek to improve the measures we used in our model to enhance construct validity.

Finally, we ran our analysis on single sample whose size is just adequate for a model of this size and complexity. Thus, we could not do any validation of the model. Other studies may further improve the model and test its validity by applying it to different data.

\section{CONCLUSION}

In this study we wanted to explore the applicability of management innovation theory on the company level in the conditions of immature and underdeveloped markets. Therefore, relying strongly on the existing knowledge base we focused our efforts on the design of a theoretical model of management innovation and its subsequent adaptation to the market conditions of the F B\&H.

The study showed that all existing theoretical propositions apply to the economic and market circumstances of the F B\&H. In addition, our analysis has shown that all but one of the proposed hypotheses are supported, and that the theoretical model designed for management innovation is valid and applicable to the market conditions of the F B\&H.

The coming period will definitely pose new and unprecedented business challenges to all contemporary companies. In order to properly address those challenges, companies will have to invent or to acquire new management models, which can be built only through a series of successful management innovations. Thus, the phenomenon of management innovation will become more and more important both for the practitioners of management and management scholars.

\section{REFERENCES}

Abrahamson, E. 1991. Management Fad and Fashions: The Diffusion and Rejection of Innovations. Academy of Management Review, 16(3): 586-612.

Abrahamson, E. 1996. Management Fashion. Academy of Management Review, 21(1): 254-285.

Abrahamson, E., Fairchild, G. 1999. Management Fashion: Lifecycles, Triggers and Collective Learning Processes. Administrative Science Quarterly, 44(4): 708-740.

Anderson, J.C., Gerbing, D.W. 1988. Structural Equation Modeling in Practice: A Review and Recommended TwoStep Approach, Psychological Bulletin, 103(3): 411-423.

Biagi, F., Parisi, M.L., Vergano, L. 2008. Organizational Innovations and Labor Productivity in a Panel of Italian
Manufacturing Firms. Working paper prepared for the XXIII National Congress of Labor Economics, Brescia, 1112 September 2008.

Birkinshaw, J. 2010. Reinventing Management. New York: Jossey-Bass.

Birkinshaw, J., Hamel, G., Mol, M.J. 2005. Management Innovation. Advanced Institute of Management Research, Available at: http://www.managingpeoplebook.com/ userimages/aim_management_innovation.pdf. Accessed 21 August 2014.

Birkinshaw, J., Hamel, G., Mol, M.J. 2008. Management Innovation. Academy of Management Review, 33(4): 825-845.

Birkinshaw, J., Mol, M.J. 2006. How Management Innovation Happens. MIT Sloan Management Review, 47(4): 81-88.

Blunt, P.2002.Public Administrative Reformand Management Innovation for Developing Countries. Available at: http:// unpan1.un.org/intradoc/groups/public/documents/un /unpan006226.pdf. Accessed 21 August 2014.

Bryson, A., Dale-Olsen, H., Barth, E. 2009. How Does Innovation Affect Worker Well-being? Centre for Economic Performance, CEP Discussion Paper No. 953. Available at: http://cep.lse.ac.uk/pubs/download/ dp0953.pdf. Accessed 21 August 2014.

Camelo-Ordaz, C., de la Luz, F-A.M., Salustiano, M-F. 2006. Influence of Top Management Team Vision and Work Team Characteristics on Innovation, European Journal of Innovation Management, 9(2): 179-201.

Central Bank of Bosnia and Herzegovina. 2014. Annual Report 2013. Sarajevo: Central Bank of Bosnia and Herzegovina.

Čaušević, F. 2012. Economic Perspectives on Bosnia and Herzegovina in the Period of Global Crisis, South East European Studies at Oxford, Opinion Piece. Available at: http://www.sant.ox.ac.uk/seesox/opinionpieces/ Causevic-Economicperspectives.pdf. Accessed 21 August 2014.

Černe, M., Jaklič, M., Škerlavaj, M. 2013. Management Innovation in Focus: The Role of Knowledge Exchange, Organizational Size, and IT System Development and Utilization. European Management Review, 10: 153-166.

Damanpour, F., 1987. The Adoption of Technological, Administrative, and Ancillary Innovations: Impact of Organizational Factors. Journal of Management, 13(4): 675-688.

Damanpour, F. 1991. Organizational Innovation: A MetaAnalysis of Effects of Determinants and Moderators. Academy of Management Journal, 34(3), 555-590.

Damanpour, F. 1992. Organizational Size and Innovation. Organization studies, 13(3): 375-402.

Damanpour, F., Aravind, D. 2012. Managerial Innovation: Conceptions, Processes, and Antecedents, Management \& Organization Review, 8(2): 423-454.

Damanpour, F. 2014. Footnotes to Research on Management Innovation. Organization Studies, 35(9): 1265-1285. 
Finney, S.J., DiStefano, C. 2006. Non-normal and Categorical Data in Structural Equation Modeling. In Hancock, G.R., Mueller, R.O. (Eds.), Structural Equation Modeling: A Second Course. Charlotte: Information Age Publishing.

García-Zamora, E., González-Benito, Ó., \& Muñoz-Gallego, P.A. 2013. Organizational and environmental factors as moderators of the relationship between multidimensional innovation and performance. Innovation: Management, policy \& practice, 15(2): 224-244.

Gruber, W.H., Niles, J.S. 1972. Put Innovation in the Organization Structure. California Management Review, 14(4): 29-35.

Gruber, W.H., Niles, J.S. 1974. How to Innovate in Management. Organizational Dynamics, 3(2): 30-47.

Guest, G., Bunce, A., Johnson, L. 2006. How Many Interviews Are Enough? An Experiment with Data Saturation and Variability, Field Methods, 18(1): 59-82.

Hair, J.F., Black, W.C., Babin, B.J., Anderson, R.E. 2009. Multivariate Data Analysis. $7^{\text {th }}$ Edition, Upper Saddle River: Prentice Hall.

Hamel, G. 2006. The Why, What, and How of Management Innovation. Harvard Business Review, 84(2): 72-84.

Hamel, G. 2007. The Future of Management. Boston: Harvard Business School Press.

Hamel, G. 2012. What Matters Now: How to Win in a World of Relentless Change, Ferocious Competition, and Unstoppable Innovation. New York: Jossey-Bass.

Hargrave, T.J., Van de Ven, A.H. 2006. A Collective Action Model of Institutional Innovation. Academy of Management Review, 31(4): 864-888.

Hecker, A., Ganter, A. 2013. The Influence of Product Market Competition on Technological and Management Innovation: Firm-Level Evidence from a Large-Scale Survey. European Management Review, 10(1): 17-33.

Hervás-Oliver, J-L., Peris-Ortiz, M. 2014. Management Innovation. Antecedents, Complementarities and Performance Consequences. Cham: Springer.

Hindle, T. 2008. Guide to Management Ideas and Gurus. London: Profile Books Ltd.

Hollen, R.M.A., Van Den Bosch, F.A.J., Volberda, H.W. 2013. The Role of Management Innovation in Enabling Technological Process Innovation: An InterOrganizational Perspective. European Management Review, 10(1): 35-50.

Jöreskog, K.G. 2004. Structural Equation Modeling with Ordinal Variables Using LISREL, Scientific Software International, Available at: http://www.ssicentral.com/ lisrel/techdocs/ordinal.pdf. Accessed 21 August 2014.

Khana, T. 2014. Contextual Intelligence. Harvard Business Review, 92(9): 58-68.

Kimberly, J.R. 1981. Managerial Innovation. In P.C. Nystrom \& W.H. Starbucks (Eds.), Handbook of organizational design, Volume 1: Adapting Organizations to their Environments. Oxford: Oxford University Press. pp. 84-104.
Kimberly, J.R., Evanisko, M.J., 1981. Organizational Innovation: The Influence of Individual, Organizational and Contextual Factors on Hospital Adoption of Technologies and Administrative Innovations. Academy of Management Journal, 24(4): 689-713.

Kossek, E.E. 1987. Human Resources Management Innovation. Human Resource Management, 26(1): 71-92.

Kunz, J., Linder, S. 2011. Managerial Innovation: Role of Employees' Needs and Attitudes. Copenhagen Business School. Available at: http://www.cbs.dk/content/download/115702/1564769/file/Managerial\% 2520Innovation\%2520-\%2520Role\%25200f\%2520Emp loyees\%2527\%2520Needs\% 2520And\%2520Attitudes. pdf. Accessed 19 December 2011.

Mamman, B.A. 2009. From Management Innovation to Management Practice. International Journal of Organizational Innovation, 2(2): 22-60.

McCabe, D. 2002. 'Waiting for dead men's shoes': Towards a cultural understanding of management innovation. Human Relations, 55(5): 505-536.

McGrath, J.E. 1981. Dilemmatics - The Study of Research Choices and Dilemmas. The American Behavioral Scientist 25(2): 179-210.

Mol, M.J., Birkinshaw, J. 2007. Giant Steps in Management: Innovations That Change the Way You Work. Harlow: Financial Times/ Prentice Hall.

Mol, M.J., Birkinshaw, J. 2009a. Management Innovation in the UK. DIUS Research Report 09-07. Available at: http:// www.bis.gov.uk/assets/biscore/corporate/ migratedD/ publications/D/DIUS_RR_09_07. Accessed 19 December 2011.

Mol, M.J., Birkinshaw, J. 2009b. The Sources of Management Innovation: When Firms Introduce New Management Practices. Journal of Business Research, 62(12): 1269-1280.

Mol, M.J., Birkinshaw, J. 2014. The Role of External Involvement in the Creation of Management Innovations. Organization Studies, 35(9): 1287-1312.

Nguyen, T.T.U., Mothe, C. 2008. Assessing the Impact of Marketing and Organizational Innovations on Firm Performance. Public Research Centre Henry Tudor. Available at: http://webserver.tudor.lu/cms/lu2020/publishing.nsf/0/A1D3EBE7C542CC99C12575140048AB72/ \$file/16h30_NGUYEN_MOTHE.pdf. Accessed 21 August 2014.

Nickell, S., Nicolitsas, D., Patterson, M. 2001. Does Doing Badly Encourage Management Innovation. Oxford Bulletin of Economics and Statistics, 63(1): 5-28.

Onwuegbuzie, A.J., Leech, N.L. 2007. A Call for Qualitative Power Analyses. Quality \& Quantity, 41(1): 105-121.

Srnka, K.J., Koeszegi, S.T. 2007. From Words to Numbers: How to Transform Qualitative Data into Meaningful Quantitative Results. Schmalenbach Business Review: ZFBF, 59: 29-57. 
Stata, R. 1989. Organizational Learning-The Key to Management Innovation. MIT Sloan Management Review, 30(3): 63-74.

Stata, R. 2002. Management Innovation. Leadership Excellence, 9(6): 8-9.

Teece, D.J. 1980. The Diffusion of an Administrative Innovation. Management Science, 26(5): 464-470.

Ursič, D., Mulej, M. 2005. Theory and Practice of Management Concepts: Slovenia's Experiences. Journal of Management Development, 24(10): 856-878.

Vaccaro, I.G., Jansen, J.J.P., Van Den Bosch, F.A.J., Volberda, H.W. 2009. Management Innovation: Uncovering the Influence of Top Management Teams. Copenhagen Business School Management Innovation Conference. Available at:http://www.cbs.dk/en/layout/set/print/content/download/115700/1564763/file/Management\%20 Innovation\%20-\%20Uncovering\%20The\%20Influence $\% 200$ f\%20Top\%20Management \%20Teams.pdf. Accessed 19 December 2011.

Vaccaro, I.G., Jansen, J.J.P., Van Den Bosch, F.A.J., Volberda, H.W. 2012. Management Innovation and Leadership:
The Moderating Role of Organizational Size. Journal of Management Studies, 49(1): 28-51.

Walker, R.M., Damanpour, F., \& Devece, C.A. 2011. Management Innovation and Organizational Performance: The Mediating Effect of Performance Management. Journal of Public Administration Research and Theory, 21(2): 367-386.

Wood, J.M. 2007. Understanding and computing Cohen's Kappa: a tutorial. WebPsychEmpiricist. Available at: www. wpe.info/vault/wood07/Wood07.pdf. Accessed 21 August 2014.

World Bank. 2014. Doing Business 2015: Going Beyond Efficiency. Washington, DC: World Bank Group.

Yang, H.M., Choi, B.S., Suh, M.S. 2007. Supply chain management six sigma: a management innovation methodology at the Samsung Group. Supply Chain Management, 12(2): 88-95.

Wu, W., Chen, Q., Yu, B., He, H. 2008. Effects of Management Innovation on Telecommunication Industry System. WSEAS Transactions on Systems, 7(5): 455-465. 